\title{
Semantic field "appearance": gender specificity (based on the English, German and Russian languages)
}

\author{
Khiadi Batkhieva ${ }^{1, *}$, Marina Levchenko ${ }^{1}$, and Veronika Shabanova ${ }^{1}$ \\ ${ }^{1}$ Moscow Region State University, 105005, Radio str, 10A, Moscow, Russia
}

\begin{abstract}
This study presents the results of a comparative analysis of the gender of lexical units with the seme "appearance" in the German, English and Russian languages. Fantasy books were used as the research material. The carried out comparative analysis of the gender aspect using the field method in Russian, English, German shows that in the studied languages, along with similarities, there are also differences in gender representation due to the specifics of the language. Comparative analysis of the semantic field "Appearance" allowed identifying the use of gender-relevant means in three languages, which confirms the fact that gender, as a socio-cultural construct, finds a vivid expression in different linguistic cultures.
\end{abstract}

\section{Introduction}

The first gender studies in linguistics began to be carried out in the Western humanities. These studies are caused by the formation of new views on the study of problems of intelligence, philosophy of science and philosophy of society (Whorf B., [1] Goffman E. [2] Lakoff, R. T. [3])

Learning language and gender together has to do with the influence of gender on the way we use language. Chris Whedon characterized language as "a place where real and possible forms of social organization and their probable social and political consequences are determined and disputed. But it is also a place where our sense of self, our subjectivity is formed" [4, p. 46]. Gender is one of the key determinants of language variation.

The concept of "gender" is regarded as one of the most problematic in this area of linguistics. The main attention of linguists was paid to the distinction between the terms "gender" and "sex". Cameron points out that the "correlation" relationship between sex and gender is usually considered in one of two possible ways: firstly, gender behavior is "built" on pre-existing sex differences and, secondly, the relationship between sex and gender can be arbitrary, but always there will be gender differences in behavior, which then "shape" gender [5].

Early pre-feminist linguistic research ranged from the view that feminine and masculine languages signal biological differences to the view that it symbolized social gender roles. Linguists who identify themselves as feminists shared the latter opinion [5].

\footnotetext{
${ }^{*}$ Corresponding author: nv.polyakova@mgou.ru
} 
The first approach to confirming this idea can be found back in 1922 in the work of the Danish linguist Otto Jespersen. Jespersen stated some gender differences [6]: women use more adverbs in their speech, giving it intensity due to a tendency to hyperbole; women do not finish their sentences because they have not thought through to the end what exactly they are going to say; men are linguistic innovators, and women have less extensive vocabulary than men.

In contrast to such works, there is a huge amount of gender and language studies (Deborah Tannen "You just don't understand me. Women and men in dialogue" [7], Wodak Ruth "Gender and Discourse" [8], Kirilina, A. V. "Gender: linguistic aspects" [9], Spender Dale "Man Made Language" [10]) conducted from the beginning of 1970 to the present day.

Fiction texts are of great interest for linguistics from the perspective of a gender approach, since they are usually built on stereotypes based on ideas of masculinity / femininity.

Gender and language were linked in scholarly work long before the second wave of the women's movement in the late 1960s and early 1970s (e.g. Jespersen 1922, [6] Labov 1966 [11]). The main focus of the content analysis approach was "quantifying images and activities". The ratio of the number of male characters to female characters, in what roles they were portrayed, and what terminology was used to describe representatives of different genders. The results of such studies resulted in the following conclusion: there were more male characters, and they covered a much wider range of professional activities than women (Manukhina, I. A. [12], Kostikova I. V. [13]).

This paper studies the content of the concept of "gender representation" of the semantic field "Appearance". For a precise definition of what is included in this concept, reference is made to linguistic research and the data of explanatory dictionaries. "The outer part or side, the exterior, which is seen from above, around, on the surface, around, and not inside" [14, p. 532]. At the same time, the texts of the turn of the 20th-21st centuries are used as representative texts in the paper, since it is the situation of the borderline that activates the fixation of gender markers, which are largely constructed and transmitted by the fiction texts. Inherently speculative, fantasy is not tied to reality or scientific fact. S. Lukyanenko said about this: "Each text is the creation of the world. Sometimes it's completely new world" $[15$, p. 56]. Therefore, literary texts of the popular genre "fantasy" are used as the research material, namely: the first book from the cycle "A Song of Ice and Fire" "Game of Thrones" by George Martin [16], the first and second books from the series "Watches" "Night Watch" and "Day Watch" by Sergei Lukyanenko [17, 18], the first part from the "Ink" trilogy "Tintenherz" by Cornelia Funke [19].

\section{Methods}

When analyzing the literary material, the following research methods were used: the method of traditional linguistic analysis; the method of continuous sampling to identify some common conceptual categories of expression and the detection of common semantic features between words; the method of comparative analysis to identify the differences between the three compared languages, the comparative method to identify various diverse individual author's manifestations in the semantics of the studied texts, as well as the field method, since this method is one of the main methods of analyzing the semantic phenomena of a language.

The analysis examines words that are somehow related to the vocabulary included in the lexical-semantic field "Appearance", which give a portrait characteristic. These lexical units provide an opportunity for further consideration and study of them regarding their own and opposite gender identity, on the basis of which the range of linguistic means of 
realizing gender stereotypes is established, as well as the most common gender stereotypes in the linguistic cultures declared for research are revealed.

On the lexical and semantic basis, lexemes related to the description of appearance in the novel "Game of Thrones" are classified into the following subgroups:

Table 1. Lexical and semantic groups in English.

\begin{tabular}{|l|c|}
\hline \multicolumn{1}{|c|}{ Subgroup } & $\mathbf{\%}$ \\
\hline Haircoat (color, length, structure) & $18 \%$ \\
\hline Eyes (color, size, peculiarities) & $11 \%$ \\
\hline Face features (color, peculiarities) & $22 \%$ \\
\hline Age & $12 \%$ \\
\hline Figure (constitution, height) & $15 \%$ \\
\hline Paraphernalia (clothes) & $12 \%$ \\
\hline Emotional and psychological state & $10 \%$ \\
\hline
\end{tabular}

The prevailing part of such groups is characterized by the presence of such keywords that have a combined meaning and, as a rule, constitute the center of the field. Lexical units with a more narrowly focused meaning, those that are used less often, and are also part of other semantic groups, are located on the periphery.

On the lexical and semantic basis, lexemes related to the description of appearance in the Russian-language novels "Night Watch" and "Day Watch" are classified into the following subgroups:

Table 2. Lexical and semantic groups in Russian.

\begin{tabular}{|l|c|}
\hline \multicolumn{1}{|c|}{ Subgroup } & \% \\
\hline Haircoat & $10 \%$ \\
\hline Facial features & $32 \%$ \\
\hline Age & $10 \%$ \\
\hline Figure & $17 \%$ \\
\hline Paraphernalia & $11 \%$ \\
\hline Emotional and psychological state & $16 \%$ \\
\hline
\end{tabular}

According to the lexical and semantic basis, the lexical units of the description of appearance in the novel "Tintenherz" were divided into the following subgroups:

Table 3. Lexical and semantic groups in German.

\begin{tabular}{|l|c|}
\hline \multicolumn{1}{|c|}{ Subgroup } & \% \\
\hline Haar & $17 \%$ \\
\hline Gesichtszüge & $30 \%$ \\
\hline eine Altersstufe & $13 \%$ \\
\hline eine Figur & $11 \%$ \\
\hline Attribut & $18 \%$ \\
\hline Emotionaler und psychischer Zustand & $11 \%$ \\
\hline
\end{tabular}

The collected vocabulary corpus was studied according to the degree of distribution of linguistic means when describing characters of male and female gender identity in the following semantic groups: hair, eyes, age, facial features, paraphernalia, figure, psychological and emotional state.

The number of lexical units that fill the semantic group "Appearance" with a male gender identity in Russian is 265 lexemes, in English - 483, in German - 318. After examining the given examples of male gender identity from fiction works, belonging to the semantic group "Appearance", it is possible to systematize them (see table 4). 
Table 4. Systematization of lexemes SG "Appearance" of male characters.

\begin{tabular}{|l|c|c|c|}
\hline \multicolumn{1}{|c|}{$\begin{array}{c}\text { Language/ } \\
\text { Semantic group }\end{array}$} & English & German & Russian \\
\hline Hair & + & + & + \\
\hline Eyes & + & - & - \\
\hline Age & + & + & + \\
\hline Facial features & + & + & + \\
\hline Figure & + & + & + \\
\hline Paraphernalia & + & + & + \\
\hline $\begin{array}{l}\text { Psychological and } \\
\text { emotional state }\end{array}$ & + & + & + \\
\hline
\end{tabular}

The number of lexical units that fill the semantic group "Appearance" with a female gender identity in Russian is 195, in English - 389, in German - 257. As for a group with a male gender identity, the number of lexical units describing women is less. This is due to the number of female characters in each of the novels in question. After examining the given examples of male gender identity from works of fiction, belonging to the semantic group "Appearance", it is possible to systematize them (see table 5).

Table 5. Systematization of lexemes of the SG "Appearance" of female characters.

\begin{tabular}{|l|c|c|c|}
\hline \multicolumn{1}{|c|}{$\begin{array}{c}\text { Language/ } \\
\text { Semantic group }\end{array}$} & English & German & Russian \\
\hline Hair & + & + & + \\
\hline Eyes & + & - & - \\
\hline Age & + & + & + \\
\hline Facial features & + & + & + \\
\hline Figure & + & + & + \\
\hline Paraphernalia and & + & + & + \\
\hline $\begin{array}{l}\text { Psychological } \\
\text { emotional state }\end{array}$ & + & + \\
\hline
\end{tabular}

\section{Results}

1. All semantic groups presented in tables 4 and 5 are reflected in English, German and Russian. However, the subgroup "Eyes" in English is separated into a separate group due to the variety of lexical units in this language.

2. Lexemes belonging to the "Hair" group play an important role in describing the appearance of male gender, and this lexeme functions in a fairly diverse context. The presence of hair, beard and mustache in male characters is regarded as a sign of special masculinity and vitality: The shadow of a new beard darkened his jaw [16 p. 272]; Sein Haar war dunkel wie Maulwurfsfell [19, p. 19]. The word "Haar" in German refers to the neuter gender, but the use of the pronoun "Sein" indicates that it is a description of a male character. He was sitting in a corner, squatting ... black hair cut in a military style [Russian: Он сидел в уголке, на корточках... черные волосы, по во-военному стриженные] [17, p. 90]. The personal pronoun "he" represents a male gender group.

3. The description of the eyes of both female and male characters in English is given by comparison. The pronoun "his" as an intermediate part of speech in English acquires gender marking; his eyes as cold and dark as onyx [16, p. 34];

4. The "Facial features" group has great internal detailing, since the appearance of the face and some of its parts is specified by the author (ear, forehead, nose, eyes, eyebrows, mouth). By the face, it is possible to determine the age, health status, national or regional affiliation, as well as character traits of a person. 
In English, Russian and German, the appearance of men is detailed. A beautiful appearance plays an important role for a man, although not the main one. However, the author emphasizes the masculinity of facial features, and overweight is portrayed as a male defect:

He was big and broad and growing every day, with his mother's coloring, the fair skin [16, p. 13];

In the Russian language, due to the national and cultural specifics, the description of skin color also helps to determine the nationality of male characters.

- He sat down next to the driver, a swarthy, hunched-nosed intellectual of about forty [Russian: Он сел рядом с водителем, смуглым горбоносым интеллигентом лет сорока] [18, p. 45]; The personal pronoun "he" represents a male gender group.

Er hatte seltsam weich geschwungene Lippen, fast wie die einer Frau, sie waren ebenso farblos wie der Rest seines Gesichtes [19, p. 177]. In German, the 3rd person pronouns "er", being substitutes for the names of animate entities, act as markers of masculine gender.

6. When describing men, the English language emphasizes the beauty of a young age in men:

He was a handsome youth of eighteen [16, p. 2]. In English, the pronoun is used in a gender-relevant way to refer not to individuals, but to male characters.

However, in the work in Russian, the age of the character is indicated quite directly, without means of expressiveness.

- outwardly, he really was at most thirty years old [Russian: внешне емy действительно было от силь тридцать лет] [18, p. 183].

The personal pronoun " $\boldsymbol{h} \boldsymbol{e}$ " makes it possible to represent a male gender group without specifying a specific person.

7. Confirming stereotypes, in English, Russian and German, masculinity is expressed through the absence of excessive emotionality in men and the ability to express emotions through gaze/facial expressions: it was a severe look that emphasized the hard and gaunt lines of his face [16, p. 30]; sein Gesicht wurde heiß vor Scham, als würde der Wind ihn mit dem Feuer verbrennen [19, p. 84]; the faces of the men are frozen and impenetrable blunt, the shoulders are square [Russian: морды мужчин каменные, плечи квадратные, лица непроницаемо-туповатье] [18, p. 48].

8. When describing male characters, fantasy authors focus on masculinity. Masculinity refers to the powerful nature of men, bestowed upon them by society and culture. It consolidates the various social positions in which culture divides people. In the English language, a large number of lexical units have been identified that describe the physique and height of male characters, since physical data is often an integral characteristic of masculinity: Khal Drogo was a head taller than the tallest man in the room [16 p. 34]; Basta war kein großer Mann, seine Schultern waren fast so schmal wie die eines Jungen [19 p. 134]; tall, stately handsome blond with the figure of Apollo [Russian: высокий, статный красавец - блондин с фигурой Аполлона] [17,p. 50];

9. Examples describing female beauty are presented in three languages - English, Russian and German. Beauty or lack thereof in women is directly related to the face, physique plays a secondary role: Sansa had gotten their mother's fine high cheekbones [16, p. 66]; she had a thin face, sunken cheeks, pale skin [Russian: y нее было худое лицо, впалье щцеки, бледная кожа] [17 p. 11]; Meggie - ein schlankes Mädchen mit hellen, glatten blonden Haaren und blauen Augen. [19, p.8].

10. All languages talk about the external signs of aging and psycho-somatic changes in old age. No one really knew how old she was, but his father said he had been calling her Old Nan even when he was a boy [16, p. 231]; - and a young, outwardly very young woman was sitting on a stool. About twenty five years (there is an intensification) [Russian: 
а на табуретке сидела молодая, внешне совсем молодая женщина. Лет двадиати nяти] [17, p.53]; «Wie alt ist sie jetzt»Staubfinger läcelte ihr zu. «Zwölf» - antwortete Mo $[19$, p.14]. At the same time, the given examples regarding the age of women are stylistically neutral in color, they do not talk about the positive - about the mind and experience of an elderly woman, and also do not provide negative features of old age or positive features of youth.

It can be said that special attention is paid to female beauty only in English, as in the case of considering the representation of male gender. Russian and German authors focus less attention on the description of female characters, do not emphasize their beauty, or its absence, as if emphasizing the specifics of the unreality of fantasy.

11. Women tend to express their state at the moment emotionally, and examples from English, Russian and German languages confirm this: A terror as overwhelming as anything Sansa Stark had ever felt filled her [16, p.139]; dull, glazed eyes of girls, cutlery clenched in fingers [Russian: mупье, остекленевшие взгляды девушек, в пальцах сжаты столовые приборы] [18, p. 197]; Ihre Stimme klang barsch wie immer, aber es klang noch etwas anderes heraus - ein schlechtes Gewissen [19, p. 95].

\section{Discussion}

The purpose of this study is to analyze the semantic component of the depiction of gender roles in the collection of descriptions of the appearance of the heroes of fictional works of the fantasy genre in English, German and Russian.

Comparative analysis of the studied lexical and semantic field consisted of four stages:

1) determination of the constituent composition of the field in the three studied languages;

2) establishing the structural and semantic organization of the semantic field, i.e. dividing it into groups (macropolis - female and male gender);

3) separation of macrofields into microfields;

4) comparative analysis of lexical units, depending on the described gender of the selected constituent composition of the semantic field "Appearance" in the three studied languages.

As a result of the continuous sampling, we can say that the authors of the studied works very actively use the description of the appearance of the characters as a kind of key that can show some features of the image of his characters, depending on their gender in a particular literary genre.

When considering the gender aspect of the "Appearance" semantic field, one can note the predominance of ideas in which psychophysiological characteristics dominate in the image of an ideal man, differentiating a man from women, namely, masculine dignity and masculine personality traits. However, for the female gender group, it is only in English that the admiration for female beauty stands out. In the Russian and German languages, a rather modest description of the appearance of female characters is given only in order to enable the reader to imagine their fantastic images himself.

\section{Conclusion}

Comparative analysis of the semantic field "Appearance" in multilingual literary texts of the fantasy genre helped to identify the objective use of gender-relevant language means, which allows concluding that gender, as a socio-cultural construct, always finds creative expression in different linguistic cultures. However, in the representation of male and female gender, there is an explicit asymmetry, since persons of both sexes are represented 
in literary texts unevenly in quantitative and qualitative terms, which reflects the real ratio of the position of men and women in modern society.

\section{References}

1. B. Whorf, Language, Thought and Reality (Cambridge, Mass, MIT Press, 1956)

2. E. Goffman, Studies in the Anthropology of Visual Communications 3 (1976)

3. R.T. Lakoff, Language and Woman's Place (New York, Harper \& Row, 1975)

4. Ch. Weedon, Feminist Practice and Poststructuralist Theory (Trade Paperback, 1987)

5. D. Cameron, Language and Gender: interdisciplinary perspectives (Harlow, Longman, 1995)

6. Otto Jespersen, Language: Its Nature, Development, and Origin (London, George Allen and Unwin, Ltd., 1922)

7. D. Tannen, You just don't understand. Women and men in conversation (N.Y., 1990)

8. Wodak Ruth, Gender and Discourse (London, Sage, 1997)

9. A.V. Kirilina, Gender studies in linguistics and communication theory: a textbook for students of higher educational institutions (M., ROSSPEN, 2004)

10. Spender Dale, Man Made Language (Routledge \& Kegan Paul, 1980)

11. W. Labov, The Social Stratification of (r) in New York City Department (Washington DC, Center for Applied Linguistics, 1966)

12. I.A. Manukhina, Language and mentality: collection of articles ( $\mathrm{SPb}, \mathrm{SPbSU}, 2010)$

13. I.V. Kostikova, Introduction to gender studies: textbook for university students (M., Aspect Press, 2005)

14. V.I. Dal, Explanatory Dictionary of the Living Great Russian Language (M., "TERRA", 2000)

15. S.V. Lukyanenko, Conductor from here Collection (AST Transitbook, 2006)

16. G.R.R. Martin, Game of Thrones (Harper Collins UK, 1998)

17. S.V. Lukyanenko, Night Watch. Genre: Fantasy (Publishing house AST, 2004)

18. S.V. Lukyanenko, Day Watch. Genre: Fantasy (Publishing house AST, 2006)

19. K. Funke, Tintenherz Gebundenes Buch (2003) 